\title{
Perceptions of a COVID-19 education public service announcement in Nunukan Regency, North Kalimantan: A qualitative study
}

\author{
Tiara Putri Leksono, ${ }^{1 *}$ Avinindita Nura Lestari, ${ }^{2}$ Reyfal Khaidar, ${ }^{3}$ Yuga Putri Pramesti, ${ }^{4}$ \\ Syarmila Sari, ${ }^{5}$ Lutfan Lazuardi ${ }^{6}$
}

\begin{abstract}
${ }^{1}$ Department of Medicine, Faculty of Medicine, Public Health, and Nursing, Universitas Gadjah Mada, Yogyakarta, Indonesia

${ }^{2}$ Department of Medicine, Faculty of Medicine, Universitas Islam Bandung, Bandung, Indonesia

${ }^{3}$ Department of Medicine, Faculty of Medicine, Universitas Islam Negeri Syarif Hidayatullah Jakarta, Jakarta, Indonesia ${ }^{4}$ Department of Nutrition, Faculty of Medicine, Public Health, and Nursing, Universitas Gadjah Mada, Yogyakarta, Indonesia

${ }^{5}$ Department of Islamic Economic Law, Faculty of Syariah, Universitas Islam Negeri Ar-Raniry, Banda Aceh, Indonesia ${ }^{6}$ Department of Health Policy and Management, Faculty of Medicine, Public Health and Nursing, Universitas Gadjah Mada, Indonesia
\end{abstract}

\section{KEYWORDS}

COVID-19

Nunukan regency

PSA

Qualitative study
ABSTRACT The North Kalimantan Province is considered the frontier, outermost, and least developed area in Indonesia. One of the districts with inadequate human resources is Nunukan Regency. As a result, indigenous people may be at risk to get limited information about the COVID-19 infection. Our study aimed to understand how one group of people in Nunukan Regency expressed reactions, interest, and impressions about the COVID-19 information transmitted in Bugis and Toraja versions of audio public service announcements (PSAs) released by the Health Empowerment and Education Project (HEUProject). The study was a qualitative research and used purposive sampling with seven participants from two subdistricts in Nunukan Regency. We conducted seven semi-structured, qualitative interviews. The data were analyzed qualitatively and thematically, then further interpreted and presented descriptively. Additionally, to see the variety of participants' answers concerning information transmission through PSAs, we analyzed the data using Tableau software 2020 version and presented the relative frequency of words with visual infographics called Word Clouds. The data were divided into three thematic questions: the immediate reaction, the behavioral reaction, and the impression after hearing the PSA. The study findings of the participants' immediate reactions involved following the advice on the PSAs audio, for instance, maintaining physical distance and washing their hands frequently. Most of the participants in this study have the willingness to hear, ability to understand, and also feel interested about the useful content in the audio format that apparently improves their awareness of COVID-19 information. Overall, it is immediately apparent that the language, transmission of messages, and information found in the HEUProject's COVID-19 educational PSA were understood and engaged the participants in a way that helped explain the pandemic situation. Our study supports the national usage of disease prevention with this type of media approach that could be used in public places in the future and may minimize any language gap.

(c) The Journal 2020. This article is distributed under a Creative Commons Attribution-ShareAlike 4.0 International license.

\section{Introduction}

North Kalimantan is the youngest province in Indonesia and located in the border area, or commonly called the 3T area (Tertinggal, Terdepan dan Terluar)

*Correspondence: tiara.putri.l@mail.ugm.ac.id

Department of Medicine, Faculty of Medicine, Public Health, and Nursing, Universitas Gadjah Mada, J. Farmako, Sekip Utara, Yogyakarta 55281, Indonesia
-- frontier, outermost, and least developed region. It also has 11 regional languages which become daily languages in each district. ${ }^{1,2}$ One of the districts in North Kalimantan which does not have adequate human resources is Nunukan regency. ${ }^{3}$ Recently in 2019, according to the ethnic background, most inhabitants are from South Sulawesi consisting of ethnic groups such as Toraja and Bugis. ${ }^{4}$ The common 
health issues are the lack of hygiene and health awareness, due to the lack of health facilities and also health professionals. ${ }^{3}$

Relating to COVID-19 as a national emergency, indigenous populations experience a risk of socioeconomic marginalization as they have limited capacities and opportunities to cope and adapt with limited or no access to technologies., ${ }^{5,6}$ In this case, community engagement is important because it focuses on COVID-19 messages tailored to the relevant national and local context.

Public service announcements (PSA) are promotional materials that address issues that are considered a general public concern in an attempt to increase public awareness of specific issues and in many instances, also try to influence public behaviors. Recently, the number of PSAs to promote healthy behaviors have become increasingly popular, including PSAs focused on health education.

The Health Empowerment and Education Project (HEUProject), a health-startup based in Bandung, made an initiative to create a downloadable audio as a PSA and text of COVID-19 education which was further translated into various local languages in Indonesia.

The present study aimed to understand how one group of people in Nunukan Regency, North Kalimantan expressed immediate reactions, and their behavior reactions: willingness to hear, knowledge improvement, interest, value, awareness about the content and their impressions about the information found in the Bugis and Toraja versions of the audio PSAs released by the HEUProject.

\section{Method}

\subsection{PSA by HEUProject}

In 2020, the HEUProject, a start-up based in Bandung, as a part of its National Campaign with COVID-19 Volunteers consisting of medical students in Indonesia along with the Ministry of Education and Culture and Rumah Bahasa (Language House), released a COVID-19 education PSA campaign ${ }^{7}$ that aimed to increase public literacy and awareness through a downloadable audio and script that can be played in public places.

Ethnologically, Indonesia consists of various ethnic groups with as many as $300-700$ languages in total. ${ }^{8}$ This PSA was translated into various local dialects in Indonesia, and as many as 36 local languages, including Bugis and Toraja language.

\subsection{Location, time and duration of activities}

This study was located in the sub-districts of Sebatik Tengah and Tulin Onsoi, Nunukan regency, North Kalimantan, Indonesia. The information collection was conducted between June 6-I2, 2020, when each participant was engaged between one to two hours for a semi-structured interview.

\subsection{Study sample, data collection and data analysis techniques}

This study used purposive sampling. There were seven participants in this research from two subdistricts in the Nunukan Regency. Inclusion criteria were as follows: (1) the people who understand Bugis and Toraja language, (2) live at the place where research was conducted, and (3) willing to be interviewed.

Seven semi-structured, qualitative interviews were conducted for prospective evaluation. Participants' ages ranged from 29 to 69 years old. The last education background in senior high school was noted in four persons, and the others were a junior high school, a bachelor and an elementary study background. In terms of occupation, four participants are farmers and two of them have another job as a housewife and head of RT (Rukun Tetangga or Community Association), and two other participants are a priest and a traditional market trader. The subject characteristics are listed below in Table 1.

The study participants were required to listen to the HEUProject's COVID-19 PSA before having the interviews. Participants \#1-\#3 were given the PSAs with Toraja language version and the rest heard the Bugis language version. Of the seven study participants, some indicated that they had previous exposure to this COVID-19 education via television or YouTube.

All interviews were audio-recorded and transcribed verbatim. The data were analyzed by 
Table 1. Participants characteristics

\begin{tabular}{llll}
\hline Participant & Age (years old) & Occupation & Last Education \\
\hline 1 (P1) & 69 & Farmer & Junior High School \\
2 (P2) & 45 & Priest & Bachelor \\
3 (P3) & 43 & Farmer and housewife & Elementary \\
4 (P4) & 53 & Head of RT and farmer & High School \\
5 (P5) & 48 & Traditional market trader & High School \\
6 (P6) & 50 & Farmer & High School \\
7 (P7) & 29 & Traditional market trader & High School \\
\hline
\end{tabular}

Table 2. The result summaries of the thematic questions

\begin{tabular}{lll}
\hline No & Thematic question & Result \\
\hline 1. & Immediate reaction & $\begin{array}{l}\text { The participants would be more careful for COVID-19 prevention (physical } \\
\text { distancing, wearing mask and washing their hands more often). }\end{array}$ \\
2 & Behavioral reaction & $\begin{array}{l}\text { The participants wanted to know more, interested about COVID PSA, and also } \\
\text { thought the PSA was helpful. }\end{array}$ \\
3 & Participants' impression & $\begin{array}{l}\text { The participants' impression was good. Almost all participants were } \\
\text { convenience with the language of the PSA and the message of the PSA was } \\
\text { understandable to the participants. }\end{array}$ \\
\hline
\end{tabular}

qualitative-thematic methods, then interpreted and presented in the form of a description or narrative. The responses were classified to draw a conclusion that referred to the ad theory and source of the literature based on the theme discovered. Additionally, to see the variety of participants' answers about: a) impression of message, b) important message noted, and c) comfort in information transmission through PSAs, we analyzed the data with Tableau software 2020 version and presented the relative frequency of words in the form of visual infographic called a Word Cloud. ${ }^{10}$

\section{Result}

The data results were divided into three thematic aspects, which were the immediate reactions after hearing the PSA; the behavioral reactions after hearing the PSA, including their willingness to hear, the improvement in personal knowledge regarding COVID-19, the interest in message conveyed, the COVID-19 content's value and care or awarenessabout the education of the disease; and the participant's impression of the information transmission through audio, involving the convenience in delivering PSA content, the impression of the PSA content and the important messages captured by participants. The result summaries of those aspects are shown in Table 2.

\subsection{Immediate reactions after hearing the PSA}

Based on the results of the semi-structured, qualitative interviews, it was found that all of the respondents' reactions were consistent with the educational content of the PSA, after hearing information about COVID-19 awareness. Four out of seven respondents, which were P2, P3, P4 and P7, said that they wanted to do physical distancing. Two respondents, P5 and P6, stated that they wanted to wash their hands more often before having contact with other people, touching things, and eating. Not only that, they were willing to wear a mask if they went outside. The first respondent (P1) said that he would be more careful and follow the recommendations that had been given. The people knew the importance of following the announcement to prevent COVID-19 transmission. The following responses were the statements from two of the respondents:

"After this, if I meet my friend, I don't want to get too close, I won't shake hands and hug my friends. If I go out I will wear a mask and reduce the use of public 


\section{transportation."}

(Participant \#3, Farmer and housewife, Elementary education background)

"Yes, we have to wash our hands, with flowing water."

(Participant \#5, Traditional Market Trader, High School education background)

\subsection{The behavioral reaction after hearing the} PSAs

Assessing the behavior reaction of the participants included several aspects: willingness to hear, improvement in their knowledge, interest in content, and awareness/caring in the disease education.

\subsubsection{Willingness to hear}

Majority of participants wanted to know about this COVID-19 educational PSA, while one participant (P5) said he/she already knew about this content from another media previously. The following responses were the statements from two of the respondents:

"Yes, I would like to know, if it is for our goodness to maintain our health, right?"

(Participant \#6, Farmer, Senior High School education background)

"We already know from the news, right? I've also heard on YouTube about COVID-19 in Bugis language. Yes, indeed we are really scared of this virus. Me, if I touch money from the buyer, I'Il directly wash my hands."

(Participant \#5, Farmer, Senior High School education background)

\subsubsection{Improvement in personal knowledge regarding COVID-19}

The majority of participants admitted that they got a lot of knowledge about COVID-19 after they heard the PSA. One participant (P7) stated that he already knew much about COVID-19 from other media sources, particularly television or YouTube.

"Yes, I got to know about COVID and how to prevent

it, like washing hands and referral hospital for COVID.
I do not easily believe it is a hoax."

(Participant \#1, Farmer, Junior High School education background)

"Actually, what the speaker said was something I've already heard in the news previously, whether on TV or YouTube."

(Participant \#7, Traditional Market Trader, Senior High School education background)

\subsubsection{Interest in message conveyed}

All of the participants were interested in the messages conveyed. Most participants felt the message transmission was compelling. They loved how the audio was transmitted in their language, especially for Bugis language. However, for Toraja language, some of the participants preferred to use the common means of communication, which was Bahasa Indonesia.

"The content was well delivered, I'm interested in listening, I suppose original Bugis people would definitely love to hear this audio record."

\section{(Participant \#5, Traditional Market Trader, Senior High School education background)}

"For me, I'm interested in the way of delivering the content, but if nomads who have left Toraja in a long time, I think they will forget the Toraja language and will be more interested if using Bahasa."

$$
\begin{array}{r}
\text { (Participant \#1, Farmer, Junior High School } \\
\text { education background) }
\end{array}
$$

\subsubsection{The COVID-19 content's value}

All of the respondents said the content of the message was useful for them. It was both helpful since it was also improving their knowledge, and they liked the language used.

“Ya, useful because it's improving my knowledge."

(Participant \#2, Priest, Bachelor education background)

"Useful, yesterday my niece also told me about 
COVID-19 in Bugis language. Well, that's the real Bugis language like that."

(Participant \#4, Head of RT and Farmer, Senior High School education background)

\subsubsection{Care or awareness about the education of the disease}

When it came to preventing the transmission of COVID-19, all the study participants were concerned about the educational messages about COVID-19.

"Yes, we have to care, we have to follow the recommendations issued by the government like in the audio record's content."

(Participant \#1, Farmer, Junior High School education background)

\subsection{Participants' impression of information transmission through audio}

Assessing the impression of the participants included several aspects: the convenience in delivering PSA, impression of the PSA content, and the important messages that participants could capture.

\subsubsection{The Convenience in Delivering PSA Content}

Most of the respondents said this content of the PSA delivered was convenient. The language was pleasant to hear because it was their own traditional language. Therefore, it was easy to understand. Meanwhile two participants, the sixth and seventh participants said that they just barely understood the language because the Bugis language has many types and they said the speaker was less fluent in speaking Bugis.

All the respondents' answers were analyzed using Tableau and the results are presented as a Word Cloud which is shown in Figure 1. The most frequent word for assessing the convenience of delivering PSA content was "nyaman" (convenience).

"Yes, it is convenient and easy to understand, that is my daily language, it is used more in Toraja and easy to understand."

(Participant \#2, Priest, Bachelor education background)

\section{mudah dipahami bahasa Bugis \\ mudah penyampaian \\ sangat sesuai $i_{\text {som anak }}$ nyaman \\ bercampur Bugis Makassar \\ berbicara sekali Bugis kurang fasih \\ dimengerti \\ bahasa pasaran \\ paham}

Figure 1. Word Cloud of Participants' Convenience in PSA Delivery

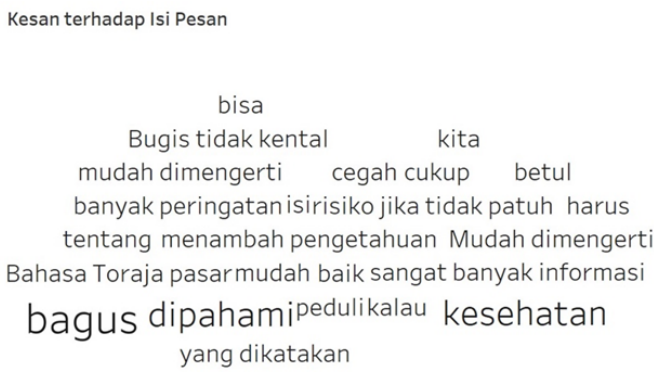

Figure 2. Word cloud of impression of the PSA's Content

"I understood. However, it seems mixed with the Bugis Makassar language, but it is understood enough. Additionally, the Bugis language has a lot of variation."

(Participant \#6, Farmer, High School education background)

\subsubsection{Impression of the PSA Content}

Four out of seven respondents, which were P1, P2, P6, and P7 said their impressions were good, either because the PSA was easy to understand, gave a lot of warning about health, or the PSA content improved their knowledge about the disease. The third respondent said the PSA contained a lot of information and was easy to understand. The fourth respondent said the content was understandable, but the pronunciation of the Bugis language was unclear. The fifth respondent said if we cared about health we had to do the prevention.

All the respondents' answers were analyzed using Tableau and the results are presented as a 
Word Cloud which is shown in Figure 2. The most frequent word for assessing the impression of the PSA content was "bagus" (good).

"For me it's good, the message of the PSA can be understood. Because the language used is Toraja daily language, not the formal one. Easy to understand."

(Participant \#1, Farmer, Junior High School education background)

"Actually, I understand the content, but the Bugis pronunciation is unclear. Oh, the Bugis language has many types, there are Makassar Bugis, Enrekang Bugis, etc... Well, maybe this Bugis is the common one to be used in society. And also, now, Bugis is rarely used, except for elderly people, but children and people at my age usually use Bahasa."

\section{(Participant \#4, Farmer and Head of RT, High School} education background)

\subsubsection{Important Message Captured by Participants}

Three out of seven respondents, mainly P2, P5, and P7 said that the messages they captured were the importance of hygiene, washing hands, and wearing a mask if going outside. Two respondents, the fourth and sixth respondents said the message they captured was the importance of physical distancing. The first participant (P1) said the message he captured was similar to the ones in television news, but transmitted in Toraja language was what makes it different. The third participant (P3) stated that the message he captured was about the development of COVID-19 in the world.

All the respondents' answers were analyzed using Tableau and the results are presented as a Word Cloud which is shown in Figure. 3. The most frequent words for the important messages captured by participants were "jaga jarak" (physical distancing) and "cuci tangan" (hand washing).

"The speaker said we have to wash our hands, wear a mask, physically distance ourselves, and then if we want to buy some food, it's better to take it away. Alternatively, it's better to cook it by ourselves at home."
(Participant \#7, Traditional Market Trader, High School education background)

"The message content is just similar with what the previous news always said, but this is in Toraja languages."

(Participant \#1, Farmer, Junior High School education background)

\subsection{Photos and figures}

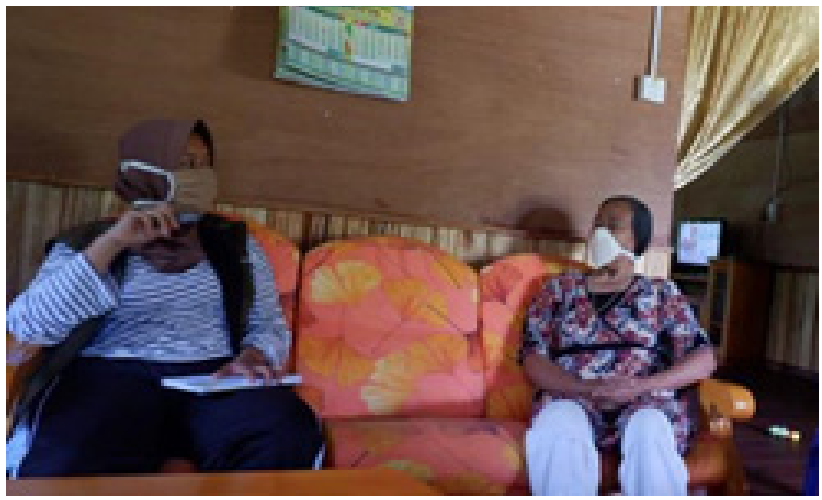

(a)

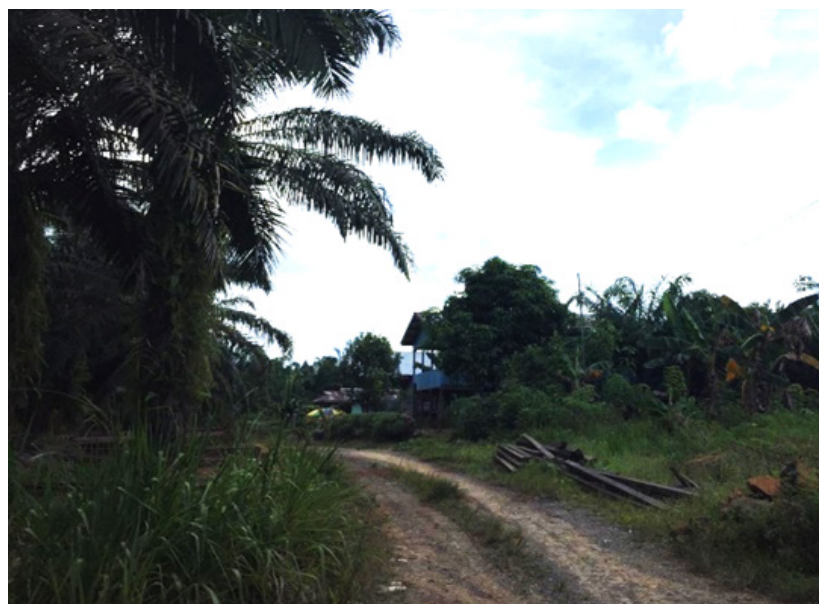

(b)

Figure 3. The Nunukan Regency. (a) Semi-structured, qualitative interview. An interview and a participant used mask and physically distanced themselves. (b) The Road view in the community field.

\section{Discussion}

As stated in the previous section, the subjects of this study were seven participants and were selected according to the inclusion criteria. Indeed, this study provided clear evidence of COVID-19 educational PSA's success in reaching some people in Nunukan 
regency as an example of indigenous populations with limitations in access to technology. However, the results of the current study indicated positive feedback as a form of their perceptions and even though they had different answers about their understanding, their reactions show the same values.

The study findings of the participants' immediate reactions included following the advice on the PSAs audio, for instance, maintaining physical distance and washing their hands frequently. This was consistent with the research that demonstrates the attitude toward an advertisement, which was further discussed in the ad theory of commercial advertisement, that explained PSAs may exert a significant positive impact on issue attitude. ${ }^{8}$ This is possible since people transfer their feelings to the media. ${ }^{8}$ Moreover, according to the research of psychological and behavioral responses to the COVID-19 pandemic, there was increased level of anxiety resulting in avoidance behaviors among people. ${ }^{11}$ This shows their immediate reactions which reflected a higher tendency for fear for their health safety.

Moreover, the content analysis of PSAs by Paletz et al. revealed depictions of cooperation among citizens as an overriding theme as well as including individual awareness. This leads to the basis of solving many societal problems. ${ }^{12}$ Reflecting on the emergency health situation, a 2007 study on a previous influenza pandemic revealed individuallevel characteristics such as age, sex, and educational status played a role in reported precautionary actions. ${ }^{5}$ This was reflected in the interview sessions where most participants in this study had the willingness to hear, to understand - despite one participant already knowing the content from another source. Besides, the participants also feel interested about the useful content in audio format that apparently improved their awareness of COVID-19 information.

Our study results showed that the audience impressions were highlighted on the use of local language, including the speaker. Three participants who heard the audio in Toraja language found it very convenient, especially for the health messages due to the usage of daily language so that they captured the content more easily. Similarly, the rest of participants who heard audio in Bugis language gave the evaluation for the speaker's fluency, even though they gave the same positive content feedback on overall content. These results are associated with the World Health Organization's bulletin ${ }^{9}$ that focuses on bridging the language divide in health, highlighting that language could be a barrier to accessing relevant and high quality information and delivering appropriate health care..$^{13}$ In public health, the linguistic aspect can create a disconnect between those providing health information and those who need that information which then can affect everyone. ${ }^{13}$

PSAs are considered to be a method of empowering community activities. The benefit is that we can amplify our ideas about current issues quickly, economically, and effectively. ${ }^{14,15}$ In addition, PSAs can be played in various places including public facilities in $3 T$ areas, such as in worship places or in the district centers through their loudspeakers. Besides that, by using PSAs, we can raise people awareness on a massive scale and encourage people to change their behavior to prevent COVID-19 transmission and take better care of themselves. ${ }^{14,15}$

A good PSA has certain provisions which include that it should have limited duration with a length of about 1 minute and a limited number of words of 125. Therefore, the message that can be delivered is also limited and must be able to deliver the content of PSA directly without any 'small talk'. Basically, PSA is a non-commercial announcement and the time it plays cannot be in a random way, so it is often played during prime time and not in the middle of the night. ${ }^{14}$

To our knowledge, this was the first study that evaluated the effectiveness of PSA in healthrelated topics in Indonesia. The strengths of our instruments include how the information was transmitted in local languages to support health promotion, could be widely transmitted and playable in any setting. This study could become a basis to conduct more campaigns and/or research in health promotions involving multimedia. Moreover, it could become a model to apply a similar mode of health communication in the future. 


\section{Conclusion}

Overall, it was immediately apparent that the language, transmission of message, and information found in the HEUProject's COVID-19 educational PSA were understood and engaged by participants in a way that helped explain the pandemic situation. This was apparent in their positive behavioral reactions and impressions towards preventive measures during the pandemic. Our study results support the national campaign with this new media approach that could be used in public places, especially in the frontier, outermost, and least developed regions of Indonesia (3T). In this case, even though our focus area, Nunukan's regency, is far from the capital of Indonesia, its population should have the same awareness and knowledge about COVID-19.

\section{Acknowledgments}

The authors would like to thank all those who have assisted in the process of accomplishing the research, and especially to the Health Empowerment and Education Project (HEUProject), Indonesia Mengajar, and all participants who were willing to be involved.

\section{Conflict of interests}

The author(s) declared no potential conflict of interest with respect to the research, authorship, and/or publication of this article.

\section{References}

1. Peta Bahasa di Kalimantan Utara [Internet]. Provinsi Kalimantan Utara - Peta Bahasa. Badan Pengembangan dan Pembinaan Bahasa, Kementerian Pendidikan dan Kebudayaan; [cited2020Jun12]. Available from: https:// petabahasa.kemdikbud.go.id/provinsi. php?idp=Kalimantan Utara

2. Rekapitulasi SDM Kesehatan yang didayagunakan di Daerah 3T (Tertinggal, Terdepan dan Terluar) di NUNUKAN, Provinsi KALIMANTAN UTARA. Badan PPSDM Kesehatan Informasi Kesehatan SDM Kesehatan. Kementerian Kesehatan Republik Indonesia; 2015.4.

3. Nawir D, Zultan A. Pemberdayaan masyarakat wilayah 3T (Terdepan,terluar, Tertinggal) di
Kecamatan Sebatik Barat Kabupaten Nunukan melalui revolusi mental dalam mewujudkan Indonesia Bersih dan Indonesia Bersatu. Jurnal Pengabdian Masyarakat Borneo. 2018;2(1):44.

4. Haba, J. Ethnic groups, development, and current situation in Nunukan. J. Kependudukan Indones. 2006; I(1);53-66.

5. Sadique MZ, Edmunds WJ, Smith RD, Meerding WJ, Zwart OD, Brug J, et al. Precautionary behavior in response to perceived threat of pandemic influenza. Emerg. Infect. Dis. 2007;13(9):130713.

6. Bardosh KL, Ryan SJ, Ebi K, Welburn S, Singer $B$. Addressing vulnerability, building resilience: community-based adaptation to vector-borne diseases in the context of global change. Infect Dis Poverty. 2017; 11(6);166.

7. Lawan COVID-19 [Internet]. Lawan COVID-19 by HEUProject. [cited 2020Jun15]. Available from: https://covid19.heuproject.com/

8. Zentz L. Statehood, Scale, and Hierarchy: History, Language, and Identity in Indonesia. Bristol, UK: Multilingual Matters. 2017. 280 pp.

9. Risk Communication and Community Engagement (RCCE) Action Plan Guidance COVID-19 Preparedness and Response [Internet]. World Health Organization. World Health Organization; [cited 2020Jun15]. Available from: https://www.who.int/publications/i/item/riskcommunication-and-community-engagement(rcce)-action-plan-guidance

10. Pandey P. Word Clouds in Tableau: Quick \& Easy. [Internet]. Medium Towards Data Science; 2019 [cited 2020Jun15]. Available from: https://towardsdatascience.com/ word-clouds-in-tableau-quick-easye71519cf507a?gi=29bf201cd788

11. Balkhi F, Nasir A, Zehra A, Riaz R. Psychological and behavioral response to the coronavirus (COVID-19) pandemic. Cureus. 2020;12(5): e7923.

12. Okeefe GJ, Reid K. The uses and effects of public service advertising. Public Relations Research Annual. 1990;2(1-4):67-91.

13. Bridging the language divide in health [Internet]. World Health Organization. World Health Organization; 2019 [cited 2020Jun15]. 
Available from: https://www.who.int/bulletin/ volumes/93/6/15-020615/en/

14. Public Service Announcement, Professor Annette Taylor, University of Dayton, 2003 Sources include: Dennis L. Wilcox, Public Relations Writing and Media Techniques, Longman, 2001; Ronald D. Smith, Becoming a Public Relations Writer, HarperCollins, 1996; Kerry Tucker, Doris Derelian, Donna Rouner, Public Relations Writing, Prentice Hall, 1994.Purposive sampling [Internet].
Research. [cited 2020Jun15]. Available from: https://research-methodology.net/sampling-inprimary-data-collection/purposive-sampling/

15. Fungsi masjid dan peranannya sebagai pusat ibadah dan pembinaan umat [Internet]. Griya PMI Asri RW.14. 2013 [cited 2020Jun15]. Available from: https://griyapmiasri. wordpress.com/2013/06/05/fungsi-masjiddan-peranannya-sebagai-pusat-ibadah-danpembinaan-umat/ 